\title{
Developing a BME Student Advocate Programme
}

\author{
Helen Barefoot, Cage Boons \\ University of Hertfordshire
}

\begin{abstract}
In 2017-18, the University of Hertfordshire designed and implemented a BME Student Advocate programme to support an institutional objective to reduce the attainment gap. Working in partnership with Hertfordshire Students' Union, ten advocates were appointed to work with each of the academic schools. Depending on the needs of their academic school, the BME student advocates carried out different activities which included: holding focus groups with BME students; representing BME students at school meetings; challenging the assumptions of staff members; critiquing curricula and the promoting race equality. Benefits for staff members included: having an advocate with whom to discuss inclusive practice ideas; receiving feedback about BME student experiences; being challenged on assumptions; forming student-staff partnerships. Staff within the University valued highly the advocates' work and, recognising its impact, the University has fully funded the programme for the next academic year.
\end{abstract}

Keywords: BME, Advocates.

\section{Introduction}

This case study provides an overview of our experience of developing a Black and Minority Ethnic (BME) Student Advocate programme to support our institutional objective to reduce the attainment gap between white and BME students.

With over 24,500 students, including more than 3,700 students from 134 different countries, the University of Hertfordshire has a very diverse student body, of which students from BME backgrounds make up approximately forty-five per cent. For over twenty years, it has been known that the proportion of BME students achieving a 'good degree' (first or upper second class) is significantly lower than the proportion of white students (Broecke and Nicholls, 2007; Berry and Loke, 2011; Equality Challenge Unit, 2017).

Through the work of the University's 'Student Performance and Monitoring Group' (SPMG) the University identified and investigated the performance gap between white and BME students. We have also taken part in national programmes to help us understand the challenges and the national context:

- 2009 HEA summit programme on BME attainment.

- 2011 HEA inclusive cultures project.

- 2015 HEA Cross-institutional project with the University of Wolverhampton and Kingston University.

- 2017-2019 HEFCE-funded collaborative project to use value added scores and inclusive curriculum discussions to drive change. 
The early Higher Education Academy (HEA) projects $(2009,2011)$ helped us to develop our arguments and provide evidence to senior members of the University about the importance of taking an institutional approach to reducing the attainment gap. We made an institutional commitment to set an equality objective to reduce the BME attainment gap ("aim to reduce the attainment gap by ten percent"). Since 2009, and following successful initiatives at institutional level, we have reduced the attainment differential by ten percentage points (attainment gap between Home/EU White and BME students in $2009=27 \%$ and in $2017=$ $17 \%)$.

Institutional activities have included:

- University committee away days to raise awareness;

- implementation of anonymous marking;

- an annual learning and teaching conference with the theme of BME student success;

- encouragement of staff to attend 'unconscious bias' training (over 700 staff members have attended);

- development of an inclusive teaching strand of our Curriculum Design Toolkit https://prezi.com/cibiptp5pa3d/curriculum-design-toolkit/ (Barefoot, 2012; Barefoot and Russell, 2012).

Institutional activities tended to focus on staff development and it had been a challenge to achieve real student engagement in discussions about the attainment gap. The 'student voice' was recognised to be missing in much of our activities. To help address this, we formed the BME Student Success Working Group (BME SSWG) in June 2016. This group had a very diverse membership and included staff and students from all ten academic schools, as well as staff from professional units within the University. The group, as part of its work, reviewed a number of data sets from within and beyond the University and found that, for almost all measures (e.g. degree attainment, employment as evidenced through Destination of Leavers of Higher Education (DLHE) data, academic confidence and academic misconduct), the outcomes for BME students - and black students in particular are somewhat bleak. Sharing this data with BME students on the working group was difficult, but it was important for all members of the group to understand fully the context and the issues.

When considering data from their academic schools, student members of the group made particularly thoughtful contributions to the discussion. We certainly gained valuable insights from their voiced experiences, which challenged the thinking of staff members and helped them to appreciate student perspectives. In particular, a black student member of the group from the School of Humanities was confident enough to share challenging experiences of racism and micro-aggressions and, rather than being angry or depressed about the data, he suggested that we employ BME students to lead change:

"I wanted us to have a visible presence on the campus and to ensure we communicated about the attainment gap to allow more students to engage in the discourse".

This led to the co-development, by the Chair of the working group and a student member of the group, of a bid for a Learning and Teaching Innovation award (£7K) to fund a BME Student Advocate programme. 


\section{Literature review - Why the title 'BME Student Advocate'?}

Hearing the 'student voice' is central to University activities, yet within our initial work to address the BME attainment gap, we focused on staff engagement and communication with our Students' Union, rather than working directly with our students and listening to their experiences and opinions. Within the UK higher education (HE) sector, student-staff partnership work has developed as an evolution of 'student voice' work. Our University is wholly committed to student-staff partnerships and we have produced resources for the sector to support student-staff partnership ventures (Jarvis et al., 2016b, 2016c and 2016d); it was therefore sensible to develop the BME student advocate project as a student-staff partnership endeavour.

As discussed by Jarvis et al. (2016a.), "student-staff partnership is a concept that is defined in different ways and has a number of purposes and practices. It generally involves students and staff working together in a way that is different from the established teaching and learning relationship in the institution". Rather than focusing on students' being coresearchers or co-creators of learning and teaching activities (Healy et al., 2014; CookSather et al., 2014) our project considered the importance of student-staff partnership to hear the 'student voice', (Czerniawski and Kidd, 2011) (especially the voice of students from BME backgrounds) and acted to develop students as 'change agents' (Dunne and Zandstra, 2011), who, through discussion and input to meetings/committees/advisory groups, would stimulate actions to reduce the attainment gap.

Although we hoped that our BME student advocates would stimulate change, we did not feel that the term 'change agent' would be appropriate, as their role would also encompass a supportive remit - one of the objectives of the role being "to create safe spaces so that BME students in the schools are able to voice any concerns, seek guidance and support and share their experiences of studying at UH'.

Another objective was "to promote race equality and be role models for other BME students" and hence we could have considered our students' acting as 'allies' - a role which is frequently adopted within social justice activity. Allies, according to Collier (2002), stand against injustice, give voice to the poor and actively respond to social oppression. The ally tends to have relative social power or privilege and stands against injustice directed at people who lack such privilege (DeTurk, 2001; Adams et al., 1997). Within HE, examples of the use of the term 'ally' have been associated with heterosexual students working as advocates on LBGTQ issues (Broido, 2000; Washington and Evans, 1991) and white students addressing racism (Bourassa, 1991). As 'allies' have tended to belong to different cultural groups from that which they support (and, within our project, we wanted to encourage students from BME backgrounds to apply for the role), we decided against the term 'ally' and instead, at the suggestion of the Vice President, Education, of our Hertfordshire Students' Union (HSU), chose the term 'advocate'.

We felt the title of 'advocate' to be appropriate, as we wanted our BME student advocates to represent BME students and to be able to raise issues associated with race equality with people in positions of power. Both of these activities are included in the Oxford English Dictionary's definition of an advocate: 
"A person who pleads for or speaks on behalf of another; a person who supports, recommends, or speaks favourably of another" (OED, 2018).

"A person who supports, recommends, or speaks in favour of something, esp. a proposal or doctrine" (OED, 2018).

\section{Development of the role descriptor}

A key objective for the BME SSWG was to understand further the experiences of students from different ethnic backgrounds; creating the BME student advocate project was seen as one of the ways to address this. Learning from similar schemes at other universities and recognising the importance of our advocates' being excellent role models for other students (NUS, 2009), we worked with our HSU Vice President, Education, and the student member of the working group who initially suggested the idea to develop a role descriptor. It was very important to do this in collaboration with our Students' Union, as we wanted the role to complement other student representation activities and not be seen as conflicting or competitive.

Drawing on elements of the University of Birmingham's 'BME Student Ambassador Scheme' (University of Birmingham, 2017) and Kingston University's 'Curriculum Consultant' project (Kingston University, 2017), we identified the following objectives for the advocates:

- To create safe spaces so that BME students in the schools are able to voice any concerns, seek guidance and support and share their experiences of studying at $\mathrm{UH}$;

- To support the careful dissemination to students of data associated with the BME attainment gap;

- To facilitate dialogue with staff members, so that the issues which may be faced by BME students in the schools may be addressed;

- To represent BME students and raise issues of concern or ideas for change at school meetings, workshops or other fora;

- To promote race equality and be role models for other BME students;

- To work with staff to improve the inclusivity of their curricula.

\section{Implementation and methods of recruitment}

In October 2017, we employed ten BME student advocates, each working with one of our academic schools. They were interviewed by a panel made up of the Chair of the BME SSWG, our Race Equality Project Officer and our HSU Vice President, Education (again in recognition of the importance of working in partnership with our Students' Union). The job advert did not preclude anyone from applying for the role and stated that applications from students from under-represented groups would be welcome. Interestingly, no white students applied for the role and, of the ten students appointed, nine students were black and one student was asian. The group of advocates included seven undergraduate students as well as three postgraduates and five of the total were international students. There were five female and five male students. The diversity of the group was hugely beneficial in itself, as their experiences, which they shared with the working group, really influenced the thinking of staff members.

The advocates were employed as 'casual' workers on hourly-paid contracts for up to four hours a week during term time. The advocates were managed by our Race Equality Project 
Officer who collected and processed their weekly time sheets. This officer communicated very regularly with them all, arranged monthly meetings with them and was the first point of contact for any queries. We designed sweatshirts for the advocates so they would be visible within their schools and accessible to students who wanted to talk to them. They also had their own information and contact cards (Figure 1).

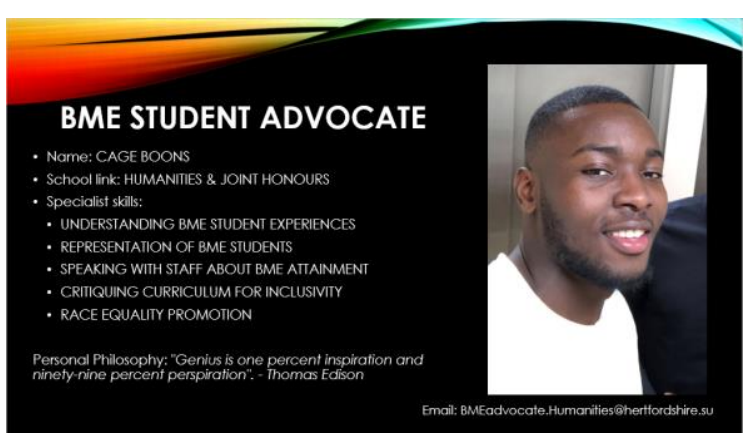

Figure 1: Copy of Cage Boons' information and contact card.

The advocates received three formal development sessions to develop specific skills (Table 1).

Table 1: Development sessions for the BME student advocates

\begin{tabular}{|l|l|l|}
\hline Training & Aim of the skills training & Conductor of the training \\
\hline Curriculum & $\begin{array}{l}\text { To have confidence in reviewing } \\
\text { teaching materials/module } \\
\text { guides/assessment briefs etc., in } \\
\text { relation to how inclusive the materials } \\
\text { are, and then to guide staff members } \\
\text { on how to enhance their materials to } \\
\text { improve the inclusivity of their } \\
\text { curricula. }\end{array}$ & $\begin{array}{l}\text { Leader of the Curriculum } \\
\text { Consultant project at } \\
\text { Kingston University plus } \\
\text { one of the Kingston } \\
\text { student curriculum } \\
\text { consultants }\end{array}$ \\
\hline $\begin{array}{l}\text { 'Unconscious bias' } \\
\text { training }\end{array}$ & $\begin{array}{l}\text { To enable advocates to become } \\
\text { aware of their own biases as well as } \\
\text { of conscious and subconscious } \\
\text { biases of others, which they may } \\
\text { encounter when speaking with staff } \\
\text { and students. (The training also } \\
\text { provided guidance on how to talk } \\
\text { about biases and to challenge biased } \\
\text { language and behaviours.) }\end{array}$ & $\begin{array}{l}\text { University's Head of } \\
\text { Equality }\end{array}$ \\
\hline $\begin{array}{l}\text { To enable advocates to develop their } \\
\text { confidence as public speakers and to } \\
\text { develop skills to lend authority to } \\
\text { their voice and message, especially } \\
\text { with people in positions of authority. }\end{array}$ & $\begin{array}{l}\text { A member of the } \\
\text { University's Board of } \\
\text { Governors, who runs this } \\
\text { type of training for } \\
\text { individuals in the private } \\
\text { sector. }\end{array}$ \\
\hline
\end{tabular}




\section{Activities and impact of the BME student advocates}

The advocates identified their specific work activities according to the needs of their academic school and negotiated/agreed this with the staff member of the BME SSWG representing the school. The advocates were also all members of the BME SSWG and attended its monthly meetings.

Amongst their activities, the advocates held focus groups with BME students (to enable us to understand better the experiences of certain groups of students), represented BME students at school meetings, challenged the assumptions of staff members, critiqued curricula, gave presentations to staff and students and promoted race equality (Figure 2). BME advocates have met with managers and subject group leaders to challenge them on the lack of inclusivity associated with race within curricula and have met with Deans of Schools to ask about actions their schools are taking to address attainment gaps with programmes.

"The most significant impact l've had as an advocate was for the Dean to accept my ideas and implement inclusive curricula actions across the school"

Some of the advocates also worked closely with our Careers and Employment Service to consider how best to promote diversity schemes to BME students and to connect with successful BME alumni.

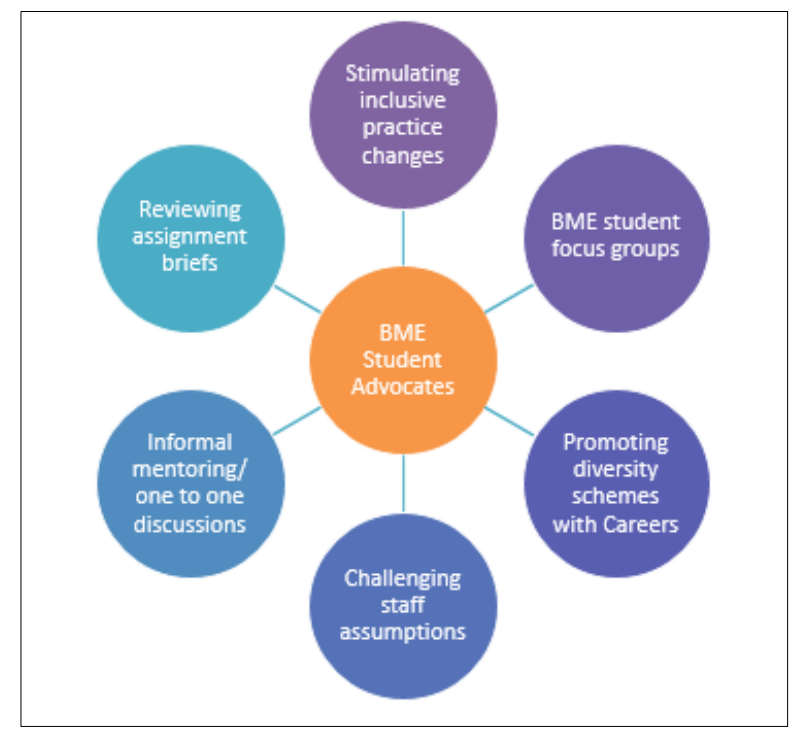

Figure 2: Some of the activities carried out by our BME student advocates during the academic year 2017/18.

Feedback from staff about the activities of the BME student advocates has been very positive. Advocates met with staff members in different roles within their schools and feedback from working group staff members indicates that the conversations the advocates facilitated have stimulated ideas and actions for members of the schools.

"Our advocate has opened up conversations about issues of race and ethnicity in a mature and constructive manner. He has not been afraid to raise difficult or sensitive issues on 
behalf of the students" Associate Dean Learning and Teaching, School of Health and Social Work.

Staff members of the BME SSWG each produced a 'school report' which reviewed actions within the school as well as provided details about the interactions and engagement with their advocate. The reports all identified the approachable nature of the advocates and their willingness to meet with students and other staff members within the school. The reports identified the benefits of sharing ideas with their advocate as well as receiving informal feedback about the experiences of BME students within their schools (see Table 2).

The advocates also produced a report on their activities and identified benefits of the role (see Table 2) as well as challenges they faced.

Table 2: Benefits for staff and advocates

\begin{tabular}{|l|l|}
\hline Benefits for staff & Benefits for the advocates \\
\hline $\begin{array}{l}\text { Having an advocate with whom to } \\
\text { discuss inclusive practice ideas }\end{array}$ & Leadership skill development \\
\hline $\begin{array}{l}\text { Receiving feedback about BME student } \\
\text { experiences }\end{array}$ & $\begin{array}{l}\text { Gained understanding of a sector-wide } \\
\text { agenda }\end{array}$ \\
\hline $\begin{array}{l}\text { Being challenged on assumptions and } \\
\text { opinions }\end{array}$ & Empowerment in discussing race \\
\hline Forming student-staff partnerships & $\begin{array}{l}\text { Ability to process, synthesise and } \\
\text { disseminate data }\end{array}$ \\
\hline
\end{tabular}

The advocates' self-evaluations recognised common challenges: of encouraging students to attend focus groups; of encountering logistical difficulties in arranging times to meet with staff members; of lacking wider awareness of the role.

The Pro Vice-Chancellor (Education and Student Experience) recognised the benefits of the advocates when she invited one of them to present at a networking event for Pro ViceChancellors. She has also invited all the advocates to be members of her Student Advisory Panel.

The advocates have made such a positive impact that they were recognised within the recent Hertfordshire Students' Union awards as 'Change Makers of the Year' (HSU 2018) and were also nominated as 'Team of the Year' within the University's Vice-Chancellor Awards (UH, 2018).

It is evident that the role has been very beneficial in terms of personal development and employability for the advocates.

"I've developed my communication skills as well as my ability to work independently as I had to use own initiative to set goals for myself and for my school". 


\section{Limitations and conclusions}

Although most BME student advocates carried out their role exceptionally well, three advocates were unable to fulfil their role as well as expected. There were various reasons for this:

1. Despite persistence by the advocate, staff members in one school were reluctant to meet with the advocate.

2. The change in personal circumstances of one of the advocates meant he could no longer easily travel to the University.

3. One of the advocates stopped communicating with the project officer and the chair of the working group and hence did not fulfil her role.

Aside from these specific issues, which in future we will monitor more closely, a common issue that all the advocates faced was difficulty encouraging BME students to attend focus groups to discuss their experiences. In future, we shall work closely with staff members to identify key times and places where our advocates can speak with students and we shall promote the focus groups more effectively.

Other challenges that the advocates faced included staff members' not acknowledging the attainment gap within their schools/programmes and staff members' being reluctant to discuss race equality. Closer collaboration with the staff member of the BME SSWG and support from the staff member to challenge these attitudes will help the advocates to tackle such issues.

The full impact of the work is difficult to measure, but our hopes that the project would increase conversations about race and enable a better understanding of BME students' experiences have certainly come to fruition. We hope that the advocates will empower other BME students and that this may become evident in confidence in contributions within the classroom, increased numbers of BME students who choose to stand as programme representatives and perhaps more BME students elected as HSU officers. We shall work with HSU to measure programme representation and election submissions.

In our initial funding bid, we suggested that, if the advocate project were to be successful within the first year of implementation, the BME SSWG would look for further funding (internal or external) to ensure the sustainability and growth of the programme. We are very pleased to report that the University has recognised the value of our BME student advocates and has agreed to fund ten more posts for the academic year 2018/19 within our Student Success commitment. We have also received inquiries from a number of other UK Universities requesting details on the programme and at least two of these are implementing a similar scheme from September 2018. 


\section{Reference list}

Adams, M., Bell, L.A. and Griffin, P. (1997) Teaching for diversity and social justice. New York, NY: Routledge. ISBN: 9781138023338

Barefoot, H.C. (2012) University of Hertfordshire Curriculum Design Toolkit. Available at: https://prezi.com/cibiptp5pa3d/curriculum-design-toolkit/ (Accessed: 1 August 2018).

Barefoot, H.C. and Russell, M.B. (2012) 'The University of Hertfordshire's Curriculum Design Toolkit.' Blended Learning in Practice, 6, 33-43. Available at:

https://www.herts.ac.uk/ data/assets/pdf file/0005/39263/BLiP-May-2012-Final-Draft.pdf (Accessed: 8 February 2019).

Bourassa, D.M. (1991) 'How White students and students of color organize and interact on campus.' New Directions for Student Services, 56, 13-23. Available at:

https://onlinelibrary.wiley.com/doi/10.1002/ss.37119915604 (Accessed: 8 February 2019).

Berry, J. and Loke, G. (2011) Improving the degree attainment of Black and minority ethnic students. London: Equality Challenge Unit/Higher Education Academy. Available at: http://www.ecu.ac.uk/wp-content/uploads/external/improving-degree-attainment-bme.pdf (Accessed: 3 August 2018).

Broecke, S. and Nicholls, T. (2007) Ethnicity and Degree Attainment. Department of Education and Skills Research Report No. RW92. Available at: https://www.education.gov.uk/publications/standard/publicationDetail/Page1/RW92 (Accessed: 3 August 2018).

Broido, E.M. (2000) 'The Development of Social Justice Allies During College: A Phenomenological Investigation.' Journal of College Student Development, 41(1), 3-18. Available at: https://psycnet.apa.org/record/2000-13605-001 (Accessed 3 August 2018).

Collier, M.J. (2002) 'Negotiating intercultural alliance relationships: Toward transformation.' In: Collier, M.J. (ed.) Intercultural alliances: Critical transformation. Thousand Oaks, CA: Sage, 49-80. ISBN: 0761925899

Cook-Sather, A., Bovill, C. and Felten, P. (2014) Engaging Students as Partners in Learning and Teaching: A guide for faculty. San Francisco, CA: Jossey-Bass. ISBN: 1118434587

Czerniawski, G. and Kidd, W. (2011) The Student Voice Handbook: Bridging the academic/practitioner divide. Bingley: Emerald Group Publishing. ISBN: 9781780520407

DeTurk, S. (2011) 'Allies in Action: The Communicative Experiences of People Who Challenge Social Injustice on Behalf of Others.' Communication Quarterly, 59(5), 569-590. Available at:

https://www.tandfonline.com/doi/full/10.1080/01463373.2011.614209 (Accessed: 8 February 2019). 
Dunne, E. and Zandstra, R. (2011) Students as Change Agents - New ways of engaging with learning and teaching in Higher Education. Bristol: ESCalate, Higher Education Academy Subject Centre for Education. Available at: http://escalate.ac.uk/8242 (Accessed: 3 August 2018).

Equality Challenge Unit (2017) Equality in higher education: statistical report 2017. Part 2: students. Available at: https://www.ecu.ac.uk/publications/equality-in-higher-educationstatistical-report-2017/ (Accessed: 3 August 2018).

Healey, M., Flint, A. and Harrington, K. (2014) Engagement through partnership: students as partners in learning and teaching in higher education. York: The Higher Education Academy. Available at:

https://www.heacademy.ac.uk/sites/default/files/resources/Engagement through partnershi p.pdf (Accessed: 3 August 2018).

Jarvis, J., Clark, K., Dickerson, C. and Stockwell, L. (2016a) 'Student-staff partnership in learning and teaching.' LINK, 2(2) Available at: https://www.herts.ac.uk/link/volume-2,-issue2/student-staff-partnership-in-learning-and-teaching (Accessed: 3 August 2018).

Jarvis, J. and Dickerson, C. (2016b) Taking down the wall: sharing perspectives: Studentstaff partnership projects in learning and teaching. A practical resource for students and staff. Hatfield: University of Hertfordshire. Available at:

http://www.studynet1.herts.ac.uk/ltic.nsf/0/52C1BE0031B2344980257FD30045F257/\$FILE/ UH\%20Staff\%20student\%20partnership\%20resource\%20-\%20final\%20\%20March\%202016.pdf (Accessed: 3 August 2018)/

Jarvis, J., Dickerson, C., Clark, K., Stockwell, L., and Clark, A. (2016c) Partnership Learning Communities. York: Higher Education Academy. Available at:

https://www.heacademy.ac.uk/sites/default/files/university of hertfordshire.pdf (Accessed: 3 August 2018).

Jarvis, J., Dickerson, C., Clark, K., and Stockwell, L. (2016d) Higher Education Academy University of Hertfordshire Strategic enhancement programme: engaged student learning. Building student-staff partnership in educational practice. Hatfield: University of Hertfordshire. Available at:

http://www.studynet1.herts.ac.uk/ltic.nsf/0/C1A04A759518716B80257FD30045E28B/\$FILE/ HEA\%20-\%20UH\%20Partnership\%20case\%20studies\%20\%20final\%20v3\%20June\%202016.pdf (Accessed: 3 August 2018).

Kingston University London (2017) New figures cement Kingston University's role as sector champion in nationwide bid to close BME attainment gap. Available at:

https://www.kingston.ac.uk/news/article/1971/15-nov-2017-new-figures-cement-kingstonuniversitys-role-as-sector-champion-in-nationwide-bid-to-close-bme/ (Accessed: 3 August 2018).

National Union of Students (2009) Race for Equality. Available at: https://www.nus.org.uk/en/news/race-for-equality/(Accessed: 3 August 2018). 
Oxford English Dictionary (2011) Definition of 'advocate' (noun). Oxford: Oxford University Press. Available at: http://www.oed.com/view/Entry/3022?rskey=jr3yQM\&result=1\#eid (Accessed: 3 August 2018).

University of Birmingham (2017) Equality Scheme 2016-2020 Advancing Equality, Valuing Diversity. Available at: http://www.birmingham.ac.uk/Documents/university/12145-TheEquality-Scheme-2016-2020-AW-Web.pdf (Accessed: 4 April 2017).

University of Hertfordshire (2016) Student Performance and Monitoring Group annual report. Hatfield: University of Hertfordshire.

Washington, J. and Evans, N.J. (1991) 'Becoming an ally.' In: Evans, N.J. and Wall, V.A. (eds.) Beyond tolerance: Gays, lesbians, and bisexuals on campus. Washington, DC: American College Personnel Association, 195-204. ISBN: 9781556200885 